\title{
126 hysterical years - the contribution of Charcot
}

\author{
Histeria 126 anos - a contribuição de Charcot \\ Hélio Afonso Ghizoni Teive', Francisco M. B. Germiniani ${ }^{1}$, Renato Puppi Munhoz ${ }^{2}$, Luciano de Paola ${ }^{3}$
}

\begin{abstract}
The authors summarise the concepts of hysteria, emphasizing the seminal contribution of Charcot to its study.

Keywords: hysteria, conversion, functional disorders.
\end{abstract}

RESUMO

Os autores fazem um resumo sobre os conceitos de histeria, enfatizando a grande contribuição de Charcot ao estudo da histeria.

Palavras-chave: histeria, conversão, distúrbios funcionais.

In its most recent edition, the Diagnostic and Statistical Manual of Mental Disorders, fifth edition (DSM-V) defined a group of conditions as functional disorders. This group comprises disorders that have at least one symptom affecting either voluntary or sensory function, or can lead to transient loss of consciousness that is not explained by an organic disorder ${ }^{1}$. Usually symptoms are not due to a general medical condition, nor are they a direct effect of a substance. Additionally, they are not considered to be a culturally sanctioned behavior or experience. One or more diagnostic features should be present as to provide evidence of internal inconsistency, or incongruity with a recognized neurological or medical disorder. The functional symptom should either cause a clinically significant distress or impairment in social, occupational, or other important areas of functioning, or it may warrant medical evaluation ${ }^{1}$.

Patients can present with a wide range of pseudo-neurological signs that can be divided in three different groups: pseudo-localizing symptoms (weakness, sensory loss, visual deficits, and pain), psychogenic movement disorders, and non-epileptic seizures; all classified as functional disorders ${ }^{1,2}$. Further classification of functional disorders according to psychiatric evaluation also varies and includes somatoform disorders, somatization disorders, conversion, and dissociative disorders. Hysteria is a classical term that encompasses all of these psychopathological states ${ }^{2,3,4}$. The aim of this historical review is to analyze the contribution of Professor JeanMartin Charcot, the father of clinical Neurology, to the study of hysteria 126 years ago (summarised in the Table).

\section{HYSTERIA IN ANCIENT TIMES}

The term hysteria was used in ancient times in texts of the Egyptians, Greeks, and Romans to describe a group of disorders that affected women, in whom symptoms were believed to be the result of "suffocation of the mother", The premise was that if the patient had no frequent sexual intercourse, the uterus would be "frustrated" by lack of proper use, leave its anatomical position and move around the body causing the symptoms; an allegory that often mentioned as either the "wandering womb", or as "the wicked womb"3,5. Hippocrates himself described hysteria as occurring in either widows or virgins, resulting from the neurotoxic effects of the "frustrated uterus",

\section{HYSTERIA BEFORE CHARCOT}

Several researchers including Charles Lepois, Thomas Willis, Thomas Sydenham, and Pierre Pomme had great interest in the study of hysteria ${ }^{5}$.

\footnotetext{
${ }^{1}$ Unidade de Desordens do Movimento, Serviço de Neurologia, Departamento de Clínica Médica, Hospital de Clínicas, Universidade Federal do Paraná, Curitiba PR, Brazil;

${ }^{2}$ Movement Disorders Centre, Toronto Western Hospital, University of Toronto, Toronto ON, Canada;

${ }^{3}$ Unidade de Epilepsia, Serviço de Neurologia, Departamento de Clínica Médica, Hospital de Clínicas, Universidade Federal do Paraná, Curitiba PR, Brazil. Correspondence: Hélio Afonso Ghizoni Teive; Rua General Carneiro, 1103/102 Centro; 80060-150 Curitiba PR, Brasil; E-mail- hagteive@mps.com.br Conflict of interest: There is no conflict of interest to declare.

Received 17 February 2014; Received in final form 05 April 2014; Accepted 25 April 2014.
} 
Table. Historical summary of researchers and different concepts regarding the origins of hysteria, from ancient times until the post-Charcot period.

\begin{tabular}{|c|c|c|c|}
\hline Time period & Researcher(s) & Concept/contribution & Rationale \\
\hline $\begin{array}{l}\text { Ancient/ classical times (Egypt, } \\
\text { Greece and Rome) }\end{array}$ & Hippocrates & Frustrated uterus & $\begin{array}{c}\text { Lack of sexual intercourse } \\
\text { Toxic effects of the Wandering } \\
\text { Womb }\end{array}$ \\
\hline \multirow[t]{2}{*}{$\begin{array}{l}18^{\text {th }} \text { and } 19^{\text {th }} \text { centuries, prior to } \\
\text { Charcot }\end{array}$} & $\begin{array}{l}\text { Ferriar } \\
\text { Briquet }\end{array}$ & $\begin{array}{l}\text { Hysterical conversion } \\
\text { Treatise on hysteria }\end{array}$ & $\begin{array}{l}\text { Sexual frustration } \\
\text { Different clinical presentations of } \\
\text { hysterical symptoms, ruled out the } \\
\text { gynecological origin }\end{array}$ \\
\hline & Laségue & $\begin{array}{c}\text { Hysterical anesthesia, ataxia, cataplexy, } \\
\text { cough }\end{array}$ & \\
\hline \multirow[t]{4}{*}{ Charcot's Salpêtrière's years } & $\begin{array}{l}\text { Charcot } \\
\text { Charcot and } \\
\text { Richer }\end{array}$ & $\begin{array}{c}\text { Hysteria as a neurological disease } \\
\text { Four stages of the hysterical attack } \\
\text { (grande hystérie): (1) Epileptoid; (2) Clownism; } \\
\text { (3) emotional gestures ("attitudes } \\
\text { passionnelles"); } \\
\text { (4) final delirium. }\end{array}$ & Dynamic, functional lesion \\
\hline & Charcot & C'est toujours la chose sexuelle & Lack of sexual intercourse \\
\hline & Charcot & Male hysteria & Traumatic shock \\
\hline & Charcot & Hypnotism & \\
\hline \multirow[t]{6}{*}{ Post-Charcot period } & Babinski & Pithiatism & Psychic state prone to suggestion \\
\hline & Janet & Subconscious & Subconscious fixed ideas \\
\hline & Freud & Conversion hysteria & \\
\hline & Freud & Therapeutical catharsis & \\
\hline & Vincent & Torpillage & \\
\hline & Yelland & Shell shock & Traumatic (war) shock \\
\hline
\end{tabular}

In the 1770s Ferriar, an English doctor, introduced the term hysterical conversion. During the eighteenth and nineteenth centuries hysteria and epilepsy were considered correlate diseases and the relationship between hysteria and sexuality, namely sexual frustration, were linked ${ }^{5}$. Hysteria could also be addressed by other names, such as hysteria libidinosa and furor uterinus. In 1859 Briquet, a French physician, published his book on the subject entitled "Treatise on hysteria". During a period of 10 years Briquet studied 430 cases of hysterical patients with different conversion symptoms, such as spasms, anesthesias, hyperesthesias, paralysis, and convulsions ${ }^{5}$. After Briquet's seminal study, the galenic-hippocratic uterine theory was changed, emphasizing the role of the brain, and hysteria was named "Briquet's disease". Another important contribution to the studies of hysteria came from Charles Lasègue, who published several studies about hysterical cough, hysterical anesthesia, catalepsy and hysterical ataxia ${ }^{5}$.

\section{CHARCOT'S CONTRIBUTION TO HYSTERIA}

Professor Charcot started his activities at the Salpêtrière hospital in 1862 and in 1882 a new discipline, the study of Diseases of the Nervous System was created for him. From that time onwards, until his death in 1893, Charcot reigned as the most celebrated neurologist of the XIX century ${ }^{3}$. He was unanimously regarded as the founder of Neurology and the Parisian Salpêtrière Hospital was aptly considered as the Mecca of World Neurology. During his time, Charcot's contributions to Neurology were enormous, including the description of several neurological diseases, such as amyotrophic lateral sclerosis (later known as Charcot's disease), multiple sclerosis ("sclérose en plaques"), Charcot-Marie-Tooth's disease (hereditary sensory and motor neuropathy), the clinical description of Parkinson's disease, Tourette's syndrome ("Maladie des tics"), tabetic arthropathy (Charcot's joints), the pathogenesis of intracerebral hemorrhage (the microaneurysms of CharcotBouchard), and studies of cerebral localization, among myriad others ${ }^{3,6}$.

By the end of his academic career, Charcot was also interested in hysteria (hysteroepilepsia) and hypnosis. In the late 1870s Charcot and the Salpêtrière's School of Neurology defined hysteria as a neurological disease, with a non-visible "dynamic or functional lesion",

The very famous anatomo-clinical method had failed in demonstrating any neuropathological lesion. Charcot and his disciple Paul Richer defined that a hysteria attack ("grande hystérie") was composed of four stages: (1) Epileptoid; (2) Contortions and acrobatic postures (Clownism); (3) Emotional gestures ("attitudes passionnelles"); and (4) final delirium ${ }^{3}$. Most of the patients studied were women and Charcot also associated hysteria to 


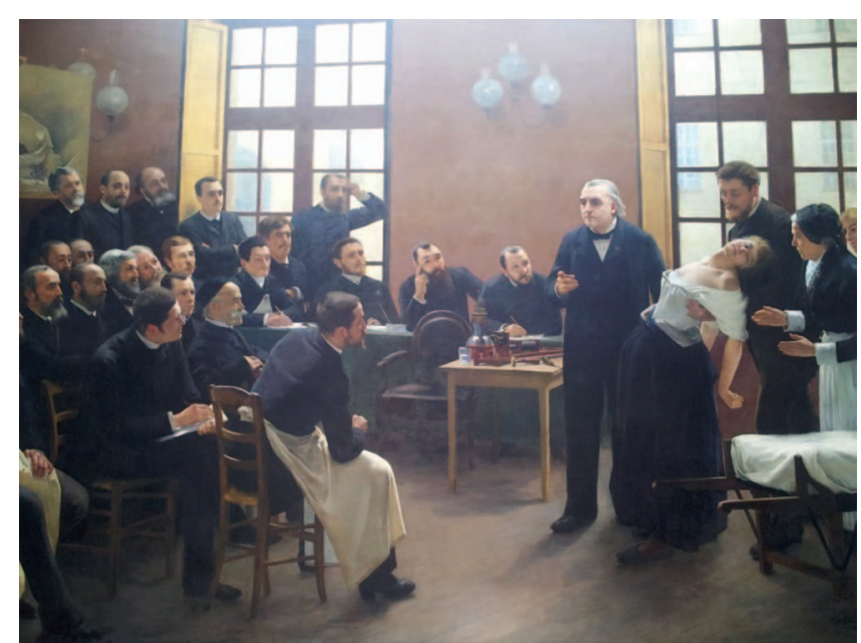

Figure. "A clinical lesson at the Salpêtrière", the original painting exhibited at the Musée de l'Histoire de la Médicine. Picture taken by one of the authors - Francisco M. B. Germiniani - at the Museum, on $18^{\text {th }}$ May 2012.

sexual intercourse, or lack thereof, even coining a very famous statement about hysteria: "c'est toujours la chose sexuelle" . After that statement, hysteria went on to become a remarkable and even trendy, fashionable disease, and Charcot's patients, including several women, some of which, such as Justine Etchevery, Rosalie Leroux, Augustine, and, particularly, Blanche Wittman (Figure), would become known worldwide ${ }^{3}$.

Charcot used hypnotism as an experimental technique to treat hysterical patients and this approach became very popular with the general public. However, in academic circles hypnosis was considered a non-scientific treatment and Charcot became the target of heavy criticism. Another contribution of Charcot was the definition of traumatic male hysteria. Finally, in 1893 Charcot stated that the Salpêtrière's concept of hysteria had become obsolete and that it needed to undergo a profound revision, but a few months later he died suddenly ${ }^{3}$.

\section{HYSTERIA AFTER CHARCOT}

After Charcot's death in 1893, the continuing investigation of hysteria had other protagonists. In the group of
Professor Charcot's disciples, Georges Gilles de la Tourette, Paul Richer, Paul Sollier and Charles Ferè published studies in accordance to the Salpêtrière's master; however, another branch of Charcot's disciples, such as Pierre Janet, Sigmund Freud and Joseph Babinski, developed other hypotheses that would clash with their mentor's vision ${ }^{5}$. Babinski defined hysteria as a psychic state that would give the patient the ability of "auto-suggestion", so that the patient would be able "to be persuaded" and therefore was prone to "healing" by suggestion". Babinski created the term "Pithiatism" and also published a study about hypnotism and hysteria ${ }^{8}$. Janet created the concept of "subconscious fixed ideas" as an underlying mechanism for hysteria, while Freud's contributions included discussing the concept of conversion hysteria and describing the first historical case of therapeutic catharsis in a famous patient, a Jewish woman named Bertha Pappenheim, a.k.a. "Ana O"3. During the first world war, across the pond, male patients would also be diagnosed with hysteria: in France, Clovis Vincent had a pivotal role with his studies and the development of the "torpillage" method of treatment, whereas in the UK, Lewis Yealland contributed by studying 196 soldiers with functional motor and sensory symptoms, functional seizures and somatoform disorders resulting from witnessing explosions ("shell shock")

\section{HYSTERIA IN THE XX CENTURY}

During most of the XX century the interest in the study of hysteria suffered a progressive decline, but by the end of the XX century and the beginning of XXI century a new interest reklinded ${ }^{10}$. Psychogenic movement disorders and nonepileptic seizures, now defined as functional disorders, represent an important group of diseases evaluated in neurological services worldwide, with expressive prevalence $e^{4,5,7}$.

In conclusion, the study of hysteria was one of the great contributions of Professor Charcot to Neurology, and although his concepts concerning it were openly criticized at the time, nowadays a new interest in the study of this still somewhat unknown condition and its intersection with neuropsychiatry has resurfaced.

\section{References}

1. Stone J, Lafrance Jr WC, Levenson JL, Sharpe M. Issues for DSM-5: conversion disorder. Am J Psychiatry 2010;167:626-627.

2. Mai FM. "Hysteria” in clinical neurology. Can J Neurol Sci 1995;22:101-110.

3. Goetz CG, Bonduelle M, Gelfand T. Hysteria. In: Goetz CG, Bonduelle M, Gelfand T (Eds). Charcot: Constructing Neurology. Oxford University Press, New York, USA, 1995:172-216.

4. Goetz CG. Charcot and psychogenic movement disorders. In: Hallet M, Fahn S, Jankovic J, Lang AE, Cloninger CR, Yudofsky SC (Eds).
Psychogenic movement disorders. Lippincott Williams \& Wilkins, Philadelphia, USA, 2006:3-13.

5. Bogousslavsky J. Hysteria after Charcot: back to the future. Front Neurol Neurosci 2013;29:137-161.

6. Teive HAG, Almeida SM, Arruda WO, Sá DS, Werneck LC. Charcot and Brazil. Arq Neuropsiquiatr 2001;59:295-299.

7. Munhoz RP, Zavala JA, Becker N, Teive HA. Cross-cultural influences on psychogenic movement disorders - a comparative 
review with a Brazilian series of 83 cases. Clin Neurol Neurosurg 2011;113:115-118

8. Philippon J, Poirier J. Pithiatism versus hysteria. In: Philippon J, Poirier J (Eds). Joseph Babinski, Oxford University Press, Oxford, UK, 2009:297-319.
9.

Linden SC, Jones E, Lees AJ. Shell shock at Quenn Square: Lewis Yealland 100 years on. Brain 2013;136:1976-1988.

10. Critchley EMR, Cantor HE. Charcot's hysteria renaissant. Br Med J 1984;289: 1785-1788 